\title{
Growth, IGF System, and Cortisol in Children with Intrauterine Growth Retardation: Is Catch-up Growth Affected by Reprogramming of the Hypothalamic-Pituitary-Adrenal Axis?
}

\author{
STEFANO CIANFARANI, CATERINA GEREMIA, CAROLYN D. SCOTT, AND DANIELA GERMANI \\ Laboratory of Pediatric Endocrinology, Department of Pediatrics, 'Tor Vergata' University, 00133 Rome, \\ Italy [S.C., C.G., D.G.]; and the Kolling Institute of Medical Research, University of Sydney, St. \\ Leonards, New South Wales 2065, Australia [C.D.S.]
}

\begin{tabular}{|c|c|}
\hline \multicolumn{2}{|c|}{ ABSTRACT } \\
\hline $\begin{array}{l}\text { Intrauterine growth retardation (IUGR) is one of the major } \\
\text { causes of short stature in childhood. Although postnatal catch-up } \\
\text { growth occurs in the majority of IUGR children, approximately } \\
20 \% \text { of them remain permanently short. The mechanisms that } \\
\text { allow catch-up growth or, on the contrary, prevent IUGR chil- } \\
\text { dren from achieving a normal height are still unknown. Our aim } \\
\text { was to investigate whether intrauterine reprogramming of hypo- } \\
\text { thalamic-pituitary-adrenal axis may be involved in postnatal } \\
\text { growth retardation of IUGR children through a modulation of the } \\
\text { function of the IGF system. Anthropometry, IGF system assess- } \\
\text { ment, cortisol measurement, and lipid profile evaluation were } \\
\text { performed in } 49 \text { IUGR children. Children were subdivided into } \\
\text { two groups according to their actual height corrected for midpa- } \\
\text { rental height: CG (catch-up growth) group, } 19 \text { children with } \\
\text { corrected height } \geq 0 \text { z-score; and NCG (noncatch-up growth) } \\
\text { group, } 30 \text { subjects with corrected height }<0 \text { z-score. CG children } \\
\text { showed significantly higher birth weight ( } p<0.005) \text { and body } \\
\text { mass index ( } p<0.05 \text { ). No significant differences in IGF-I, } \\
\text { IGF-II, IGF binding protein (IGFBP)-1, IGFBP-3, soluble IGF-II } \\
\text { receptor levels (IGF2R), IGF-II/IGF2R ratio, and relative } \\
\text { amounts of IGFBP-3 circulating forms were found between CG } \\
\text { and NCG children. None of the IGF system-related variables } \\
\text { correlated with anthropometric indices. NCG children showed } \\
\text { significantly higher concentrations of cortisol ( } p<0.005) \text { and } \\
\text { cortisol levels resulted inversely to birth weight }(r=-0.34, p< \\
0.05 \text { ), birth length }(r=-0.36, p<0.05) \text { and corrected height } \\
\text { ( } r=-0.44, p<0.01) \text {. Whereas total and HDL cholesterol } \\
\text { concentrations were not significantly different in the two groups, } \\
\text { LDL cholesterol levels were significantly higher in NCG chil- }\end{array}$ & $\begin{array}{l}\text { dren }(p<0.05) \text {, and five of } 49 \text { showed LDL cholesterol con- } \\
\text { centrations }>3.4 \mathrm{mM}(130 \mathrm{mg} / \mathrm{dL}) \text {. LDL cholesterol was in- } \\
\text { versely related to birth weight }(r=-0.31, p<0.05) \text {, corrected } \\
\text { stature }(r=-0.32, p<0.05) \text {, and actual height }(r=-0.31, p \\
<0.05) \text { and directly related to the levels of IGF2R }(r=0.44, p \\
<0.01) \text {. Reanalysis of } 15 \text { of } 30 \text { IUGR newborns in whom we } \\
\text { previously reported an inverse relationship between cord blood } \\
\text { cortisol levels and first trimester length gain }(r=-0.54, p< \\
0.005) \text { showed that the relative amount of the IGFBP-3 18-kD } \\
\text { fragment was related inversely to cortisol ( } r=-0.67, p<0.01) \\
\text { and directly to early postnatal growth }(r=0.65, p<0.05) \text {. Our } \\
\text { results suggest that catch-up growth in IUGR children might be } \\
\text { affected by intrauterine reprogramming of hypothalamic- } \\
\text { pituitary-adrenal axis, which may result in a permanent modif- } \\
\text { cation of the neuroendocrine response to stress: children with } \\
\text { increased cortisol secretion may be at higher risk of growth } \\
\text { failure. During the neonatal period cortisol might act by limiting } \\
\text { IGFBP-3 proteolysis and, therefore, reducing IGF } \\
\text { bioavailability. (Pediatr Res } \mathbf{5 1 :} \mathbf{9 4 - 9 9 ,} \mathbf{2 0 0 2 )} \\
\text { CAbbreviations } \\
\text { HPAA, hypothalamic-pituitary-adrenal axis } \\
\text { IGF2R, soluble IGF-II/mannose-6-phosphate receptor } \\
\text { IUGR, intrauterine growth retardation } \\
\text { MPH, midparental height } \\
\text { NCG, noncatch-up growth } \\
\text { IGFBP, IGF binding protein } \\
\text { CV, coefficient of variation }\end{array}$ \\
\hline
\end{tabular}

IUGR is one of the major causes of short stature in childhood, and although postnatal CG occurs in the majority of IUGR infants, approximately $15-20 \%$ of these children reach a final height

Received January 19, 2001; accepted July 30, 2001.

Correspondence and reprint requests: Stefano Cianfarani, M.D., Laboratory of Pediatric Endocrinology, Room E-178, 'Tor Vergata' University, via di Tor Vergata 135, 00133, Rome, Italy; e-mail. stefano.cianfarani@uniroma2.it lower than their genetic potential $(1,2)$. The mechanisms that allow CG in IUGR children or, on the contrary, prevent them from achieving a normal height are still unknown $(3,4)$.

IGF-I and IGF-II circulate bound to high-affinity IGFBPs (IGFBP-1 through -6), which reduce IGF bioavailability (5). Approximately $75 \%$ of circulating IGFs are bound in a ternary complex, consisting of IGF peptide, IGFBP-3, and an acid-labile subunit 
(6). The IGFBP-3 molecule may be processed by specific proteases $(7,8)$, which yield fragments with reduced affinity for IGFs, thus leading to increased IGF bioavailability (9). The balance between IGF concentrations and IGF bioavailability may therefore represent a fine mechanism of growth modulation. We have recently described the presence of IGFBP-3 proteolytic activity in sera of newborns and infants with IUGR, suggesting the intervention of at least two different proteases that break the IGFBP-3 molecule into two different fragments and eventually lead to increased IGF bioavailability (4).

Epidemiologic studies have shown that IUGR subjects would be at risk of developing non-insulin-dependent diabetes mellitus, hypertension, hyperlipidemia, and cardiovascular diseases in adult life $(10-12)$. To explain this association the concept of reprogramming was introduced: intrauterine malnutrition would induce fetal adaptation finalized to minimize the energy expenditure for growth and to favor survival and development of vital organs, such as brain. When the exposure to an insufficient supply of nutrients occurs during critical periods of fetal life, it would permanently affect the development and function of the endocrine system.

The function of the HPAA can be permanently programmed during development (13), although the pathophysiologic mechanisms remain unclear. In animals, exposures to glucocorticoids in prenatal and early postnatal life may imprint the rodent HPAA, resulting in permanent modification of the neuroendocrine response to stress throughout life $(14,15)$. In monkeys, dexamethasone treatment during pregnancy induces a reduction in hippocampal volume and an increase in plasma cortisol levels in postnatal life (16). In the fetus of the ewe undernourished in the first half of gestation, the responses of the HPAA to hypoxia or exogenous corticotrophin-releasing hormone are diminished in utero but exaggerated after birth (16). In rats, maternal undernutrition is able to induce both IUGR and fetus overexposure to maternal corticosterone, leading to HPAA dysregulation in newborns (17). In human, Phillips et al. (18) have recently suggested that elevated cortisol concentrations might represent a link between low birth weight and insulin resistance.

We have recently reported that cortisol levels correlate positively with IGFBP-1 and negatively with IGF-I in newborns with birth weight appropriate for gestational age (19). Moreover, in IUGR infants, we found an inverse relationship between plasma cortisol values and the length gain in the first trimester of life (19).

Our aim was to investigate whether intrauterine reprogramming of HPAA may be involved in postnatal growth retardation of IUGR children through a modulation of the IGF system function, and in the present study we have related postnatal CG to cortisol levels and IGF system status.

\section{METHODS}

Subjects and anthropometry. Forty-nine IUGR children (22 boys and 27 girls, aged $9.2 \pm 3.3$ y) born at term with a birth weight below the 10th centile for gestational age (20) and attending the Outpatient Growth Clinic of the Department of Pediatrics of 'Tor Vergata' University in Rome were investigated. Children with malformations or genetic disorders were excluded. All children underwent anthropometric measurements using the growth standards of Tanner and Whitehouse (21). Height was expressed as z-score for chronological age and sex according to the following formula: $\mathrm{z}$-score $=(\mathrm{x}-$ average $\mathrm{x}$ )/SD where $\mathrm{x}$ is the actual height, average $\mathrm{x}$ is the mean of the height at that age and for that sex, and SD is the SD from the mean. MPH was used as an indicator of genetic growth potential: MPH for boys $(\mathrm{cm})=$ father height + $($ mother height +13$) / 2$; MPH for girls $(\mathrm{cm})=$ mother height + (father height -13$) / 2$. Both parents of each child were measured in our clinic. Children's statures were corrected for their MPH according to the formula: corrected height (z-score) $=$ actual height $(\mathrm{z}$-score $)-$ MPH (z-score). Children were subdivided into two groups according to their corrected height: CG group, children with corrected height $\geq 0 \mathrm{z}$-score; and NCG group, subjects with corrected height $<0$ z-score. In IUGR children with actual or corrected height $\leq-2$ z-score, GH deficiency was ruled out by clonidine $\left(100 \mu \mathrm{g} / \mathrm{m}^{2}\right.$ orally) or GH releasing hormone $(1 \mu \mathrm{g} / \mathrm{kg}$ i.v. $)+\operatorname{arginine}(0.5 \mathrm{~g} / \mathrm{kg}$ i.v.) stimulation tests.

These results prompted us to reevaluate IGFBP-3 circulating forms in cord blood samples of 15 of 30 previously reported IUGR newborns (19) in whom we observed an inverse relationship between cord blood cortisol and first trimester length gain $(r=-0.54, p<0.005)$. Ponderal index [weight $(\mathrm{g}) /$ length $(\mathrm{cm})^{3} \times 100$ ] was used as anthropometric measurement to discriminate between proportionate and nonproportionate IUGR newborns (22). The investigation was approved by the Ethical Committee of the 'Tor Vergata' University Medical School, and written consent was obtained from all the parents.

Hormone and biochemical assays. Serum samples for baseline hormone assessments were collected between 0800 and $0900 \mathrm{~h}$ in fasting conditions. Serum IGF-I was measured by immunoradiometric assay (IRMA, Nichols Institute Diagnostics, San Juan Capistrano, CA, U.S.A.). The intraassay CV was $3.3-4.6 \%$, the interassay $\mathrm{CV}$ was $9.3-15.8 \%$, and the sensitivity limit was $0.78 \mathrm{nM}$. Serum IGF-II was measured by IRMA (Diagnostic Systems Laboratories Inc., Webster, TX, U.S.A.). The intraassay $\mathrm{CV}$ was $3.4-6.5 \%$, the interassay $\mathrm{CV}$ was 4.5-6.3\%, and the sensitivity limit was $1.6 \mathrm{nM}$. Serum IGFBP-3 was measured by IRMA (Diagnostic Systems Laboratories Inc.). The intraassay $\mathrm{CV}$ was $1.8-3.9 \%$, the interassay $\mathrm{CV}$ was $0.5-1.9 \%$, and the sensitivity limit was $16.4 \mathrm{nM}$. IGFBP-1 was measured by IRMA (Medix Biochemica, Kauniainen, Finland). The intraassay CV was $3.4-6 \%$, the interassay CV was $7.4-9 \%$, and the limit of sensitivity was 0.4 $\mu \mathrm{g} / \mathrm{L}$. Serum cortisol was measured by RIA (Byk-Sangtec Diagnostica, Dietzenbach, Germany). The intraassay CV was $2.1-4.0 \%$, the interassay $C V$ was $3.2-9.0 \%$, and the sensitivity limit was $13.8 \mathrm{nM}$. Soluble IGF2R levels were assayed using a novel human-specific two-site sandwich ELISA according to the method of Costello et al. (23). The interassay CV ranged from $9 \%$ to $15 \%$ and there was no cross-reactivity with IGF-II. Total and HDL cholesterol were measured enzymatically by an automatic photometric method (Boehringer Mannheim, Mannheim, Germany). For total cholesterol, the interassay CV was $3.1 \%$ at $4 \mathrm{mM}$, whereas for HDL cholesterol the interassay $\mathrm{CV}$ was $4.1 \%$ at $0.85 \mathrm{mM}$ and $3.8 \%$ at $1.69 \mathrm{mM}$. Triglycerides 
were analyzed enzymatically (Boehringer Mannheim), and the interassay $\mathrm{CV}$ was $1.6 \%$ at $2.45 \mathrm{mM}$ and $3.2 \%$ at $1.23 \mathrm{mM}$. LDL cholesterol concentrations were calculated by the Friedewald-Fredrickson formula [LDL cholesterol $=$ total cholesterol - (HDL cholesterol + triglycerides / 2.2)] (24).

Western immunoblot analysis. To visualize circulating proteolytic fragments of IGFBP-3, Western immunoblotting analysis was performed as previously described (4). Briefly, after addition of nonreducing SDS sample buffer, serum samples (3 $\mu \mathrm{L})$ were processed by SDS-PAGE $(12 \%$ gel). Separated proteins were electroblotted onto nitrocellulose filters in a Hoeffer semi-dry transphor unit (San Francisco, CA, U.S.A.). Filters were blocked with $1 \%$ BSA and sequentially incubated with sheep anti-IGFBP-3 antibody (kindly provided by Dr. J.M.P. Holly, University of Bristol, U.K.) overnight at $4^{\circ} \mathrm{C}$ and with goat anti-sheep IgG conjugated with horseradish peroxidase (Amersham International, Amersham, U.K.) for $2 \mathrm{~h}$ at room temperature. Filters were exposed to enhanced chemiluminescence reagents (Amersham) for $1 \mathrm{~min}$ at $20^{\circ} \mathrm{C}$ and exposed to hyperfilm ECL for $1 \mathrm{~min}$ to $1 \mathrm{~h}$ at $20^{\circ} \mathrm{C}$. Densitometric analysis of bands was performed using a Bio-Rad GS 700 imaging densitometer (Bio-Rad, Richmond, CA, U.S.A.). The relative amount of each IGFBP-3 circulating fragment was estimated by calculating the absorbance of the fragment band over the sum of the intact IGFBP-3 and IGFBP-3 fragments in the same lane.

Statistics. Results are reported as the mean \pm SD. Differences between means were assessed using unpaired two-tailed $t$ test and one-way ANOVA. Significance was assigned for $p<0.05$. After ascertaining that all variables were normally distributed, the relationships among variables were evaluated by Pearson correlation. All the relationships among variables were controlled for the effect of pubertal stage and body mass index (z-score). A computer program was used for all statistical calculations (BMPD Statistical Software, SOLO 3.0, Los Angeles, CA, U.S.A.).

\section{RESULTS}

Anthropometric data of IUGR children are summarized in Table 1. The CG group comprised 19 of 49 (39\%) children who achieved or improved MPH (corrected height $\geq 0$ z-

Table 1. Clinical data of IUGR children

\begin{tabular}{|c|c|c|c|}
\hline & $\begin{array}{c}\text { CG group } \\
\text { corrected stature } \\
\geq 0 \text { z-score } \\
\quad(n=19) \\
(\text { mean } \pm \mathrm{SD})\end{array}$ & $\begin{array}{c}\text { NCG group } \\
\text { corrected stature } \\
<0 \text { z-score } \\
(n=30) \\
(\text { mean } \pm \mathrm{SD})\end{array}$ & $p$ \\
\hline Age (y) & $9.9 \pm 2.5$ & $8.8 \pm 3.7$ & NS \\
\hline Birth weight (kg) & $2.37 \pm 0.29$ & $2.06 \pm 0.35$ & 0.002 \\
\hline Birth length $(\mathrm{cm})$ & $46.3 \pm 2.7$ & $45.2 \pm 2.7$ & NS \\
\hline $\begin{array}{l}\text { Ponderal index } \\
\qquad\left(\mathrm{g} / \mathrm{cm}^{3} \times 100\right)\end{array}$ & $2.27 \pm 3.3$ & $2.19 \pm 3.9$ & NS \\
\hline Height (z-score) & $-0.39 \pm 1.5$ & $-1.7 \pm 0.67$ & 0.002 \\
\hline $\begin{array}{l}\text { Height velocity } \\
\text { (z-score) }\end{array}$ & $-0.05 \pm 3.8$ & $-0.27 \pm 1.6$ & NS \\
\hline BMI $\left(\mathrm{kg} / \mathrm{m}^{2}\right)$ & $18.1 \pm 4.5$ & $15.8 \pm 3.5$ & 0.04 \\
\hline BMI (z-score) & $0.78 \pm 2.3$ & $-0.58 \pm 1.7$ & 0.02 \\
\hline MPH (z-score) & $-1.45 \pm 0.89$ & $-0.59 \pm 0.69$ & 0.001 \\
\hline
\end{tabular}

Abbreviations used: BMI, body mass index. score), whereas the NCG group comprised 30 of 49 (61\%) IUGR children who showed a corrected height below $0 \mathrm{z}-$ score. CG children showed significantly higher birth weight ( $p$ $<0.005)$, actual height $(p<0.005)$, and body mass index ( $p$ $<0.05)$, and lower MPH $(p<0.005)$ (Table 1). No significant difference in actual growth rate and ponderal index was found between the two groups.

No significant differences in IGF-I, IGF-II, IGFBP-1, IGFBP-3, and IGF2R levels, IGF-II/IGF2R ratio, and relative amounts of IGFBP-3 circulating forms were found between CG and NCG children (Table 2). None of the IGF system variables was related to anthropometric indices.

NCG children showed significantly higher concentrations of cortisol $(p<0.005$; Table 2$)$ and, in the whole group of 49 subjects (CG + NCG groups), cortisol levels were inversely related to birth weight $(r=-0.34, p<0.05)$, birth length $(r$ $=-0.36, p<0.05)$, and corrected height $(r=-0.44, p<$ 0.01 ; Fig. 1), whereas no relationship between cortisol concentrations and actual height velocity was found.

Although total and HDL cholesterol concentrations were not significantly different in the two groups, LDL cholesterol levels were significantly higher in NCG children $(p<0.05)$, and five of $49(10 \%)$ of IUGR children showed LDL cholesterol concentrations $>3.4 \mathrm{mM}(130 \mathrm{mg} / \mathrm{dL})$. LDL cholesterol was inversely related to birth weight $(r=-0.31, p<0.05)$, corrected stature $(r=-0.32, p<0.05)$, and actual height $(r=$ $-0.31, p<0.05$ ), and directly related to the levels of IGF2R $(r=0.44, p<0.01)$. The IGF2R concentrations also correlated with total cholesterol $(r=0.46, p<0.01)$ and IGF-II levels $(r$ $=0.45, p<0.01)$.

Western immunoblot analysis of IGFBP-3 revealed the presence of two major forms: the intact form represented by a doublet migrating at approximately $42-39 \mathrm{kD}$ molecular weight, and the major product of proteolysis migrating at approximately $29 \mathrm{kD}$ (Fig. 2). Densitometry did not reveal any relationship between the relative amounts of the two IGFBP-3

Table 2. Endocrine and biochemical data of IUGR children

\begin{tabular}{|c|c|c|c|}
\hline & $\begin{array}{l}\text { CG group } \\
\text { corrected stature } \\
\geq 0 \text { z-score } \\
(n=19) \\
(\text { mean } \pm \mathrm{SD})\end{array}$ & $\begin{array}{l}\text { NCG group } \\
\text { corrected stature } \\
<0 \text { z-score } \\
(n=30) \\
(\text { mean } \pm \mathrm{SD})\end{array}$ & e \\
\hline IGF-I (nM) & $37 \pm 20.8$ & $29 \pm 19.5$ & NS \\
\hline IGF-I (z-score) & $0.4 \pm 2.5$ & $0.5 \pm 3.3$ & NS \\
\hline IGF-II (nM) & $113.5 \pm 16$ & $107.5 \pm 29$ & NS \\
\hline IGF-II (z-score) & $0.48 \pm 0.65$ & $0.69 \pm 1.1$ & NS \\
\hline IGFBP-3 (nM) & $128 \pm 30$ & $117 \pm 36$ & NS \\
\hline IGFBP-3 (z-score) & $0.31 \pm 0.86$ & $0.22 \pm 1.3$ & NS \\
\hline $\begin{array}{l}\text { IGFBP-3 } \sim 29-\mathrm{kD} \\
\text { fragment }(\mathrm{OD})\end{array}$ & $0.79 \pm 0.4$ & $1.23 \pm 1.5$ & NS \\
\hline IGF-I/IGFBP-3 ratio & $69.9 \pm 28$ & $58.5 \pm 35$ & NS \\
\hline IGFBP-1 $(\mu \mathrm{g} / \mathrm{L})$ & $104 \pm 61$ & $120 \pm 45$ & NS \\
\hline IGF2R $(\mu \mathrm{g} / \mathrm{mL})$ & $1.59 \pm 0.34$ & $1.81 \pm 0.59$ & NS \\
\hline IGF-II/IGF2R ratio & $525 \pm 92$ & $487 \pm 223$ & NS \\
\hline Cortisol (nM) & $248 \pm 99$ & $381 \pm 187$ & 0.002 \\
\hline Total cholesterol (nM) & $3.9 \pm 0.8$ & $4.3 \pm 0.7$ & NS \\
\hline HDL cholesterol (nM) & $1.3 \pm 0.4$ & $1.4 \pm 0.3$ & NS \\
\hline LDL cholesterol (nM) & $2.3 \pm 0.6$ & $2.7 \pm 0.6$ & $<0.05$ \\
\hline Triglycerides (nM) & $0.6 \pm 0.3$ & $0.7 \pm 0.3$ & NS \\
\hline
\end{tabular}




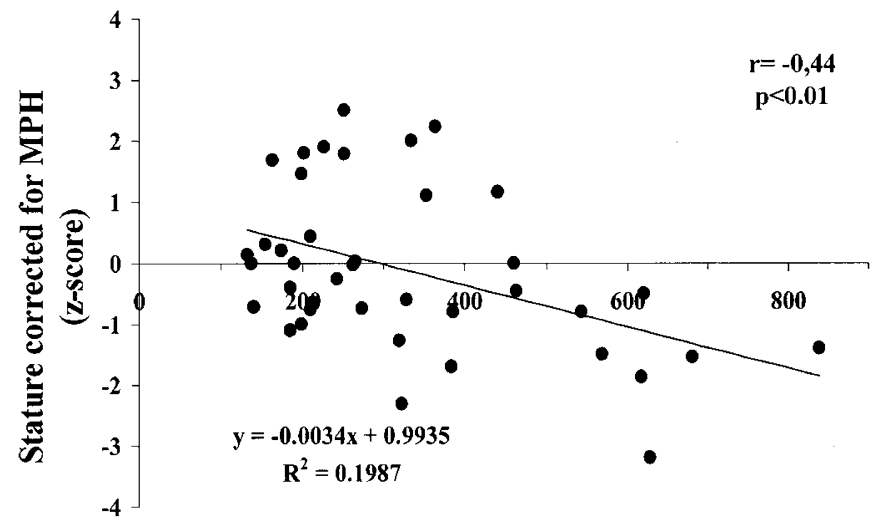

Cortisol (nmol/L)

Figure 1. Relationship between cortisol concentrations and corrected height in IUGR children. Cortisol was determined by RIA. Corrected height (z-score) $=$ actual height $(\mathrm{z}$-score $)-\mathrm{MPH}$ (z-score).

\section{IUGR children}

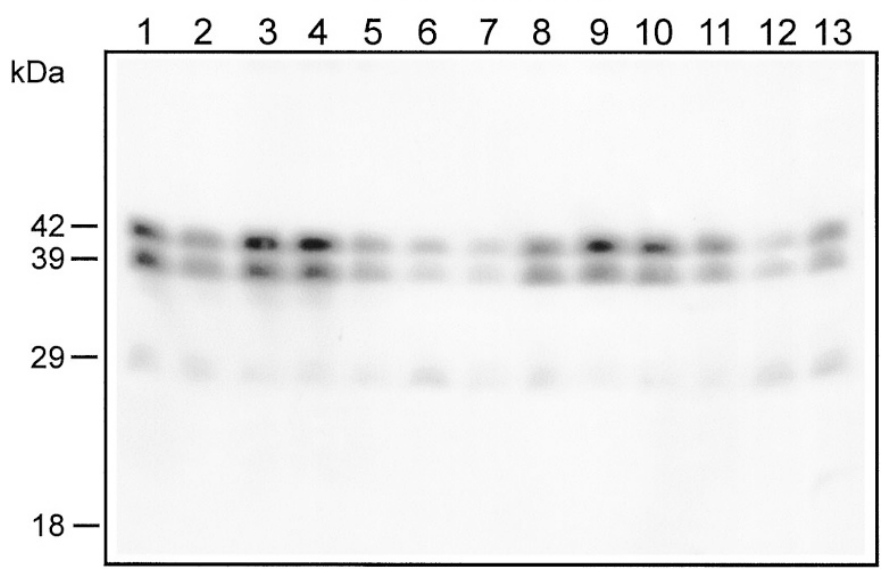

Figure 2. Detection of IGFBP-3 forms by Western immunoblotting in sera from 13 IUGR children representative of the total 49 subjects. Serum samples ( $3 \mu \mathrm{L}$ ), after addition of nonreducing SDS sample buffer, were processed by SDS-PAGE (12\% gels) and electroblotted onto nitrocellulose filters. Nitrocellulose was incubated with sheep anti-IGFBP-3 antibody, and binding after incubation with goat anti-sheep IgG-conjugated horseradish peroxidase was detected using the enhanced chemiluminescence detection system. Autoradiographs were developed after 1-60 min of exposure. Molecular mass markers are indicated on the left.

forms and the anthropometric, biochemical, and endocrine measurements.

Clinical data of IUGR newborns are reported in Table 3. IGFBP-3 immunoblot analysis revealed the presence of three different bands: the doublet approximately $42-$ to $39-\mathrm{kD}$ band corresponding to the intact form of IGFBP-3, the major IGFBP-3 fragment migrating at approximately $29 \mathrm{kD}$, and a smaller fragment of approximately $18 \mathrm{kD}$ (Fig. 3). Densitometric analysis of bands showed that the intensity of the approximately $18-\mathrm{kD}$ fragment was related positively to the length gain in the first trimester of life ( $r=0.65, p<0.05$; Fig. 4) and negatively to cortisol concentrations $(r=-0.67, p<0.01$; Fig. 5).

\section{DISCUSSION}

The vast majority of children born with IUGR (approximately $80 \%$ ) show a CG in the first 2 years of life and achieve a final
Table 3. Clinical and endocrine data of IUGR newborns

\begin{tabular}{lc}
\hline & $\begin{array}{c}\text { IUGR newborns } \\
(n=15) \\
(\text { mean } \pm \mathrm{SD})\end{array}$ \\
\hline Birth weight $(\mathrm{kg})$ & $2.28 \pm 0.21$ \\
Birth length $(\mathrm{cm})$ & $46.5 \pm 1.8$ \\
Ponderal index $\left(\mathrm{g} / \mathrm{cm}^{3} \times 100\right)$ & $2.27 \pm 0.2$ \\
IGF-I $(\mathrm{nM})$ & $2.3 \pm 1.1$ \\
IGFBP-1 $(\mu \mathrm{g} / \mathrm{L})$ & $117.1 \pm 54.9$ \\
Cortisol $(\mathrm{nM})$ & $259.3 \pm 137.9$ \\
IGFBP-3 $(\mathrm{nM})$ & $23.6 \pm 9.8$ \\
IGFBP-3 $\sim 18-\mathrm{kD}$ fragment $(\mathrm{OD})$ & $0.33 \pm 0.22$ \\
IGFBP-3 $\sim 29-\mathrm{kD}$ fragment $(\mathrm{OD})$ & $0.65 \pm 0.52$ \\
\hline
\end{tabular}

stature within the normal range according to their $\operatorname{MPH}(1,2)$. In this study, however, only 19 of the 49 IUGR children showed a height equal to or greater than their MPH. This finding may have two explanations. First, the selection of subjects may be involved, as all children enrolled in this study were recruited from our growth clinic where they were referred for a suspicion of growth retardation. Second, none of our children had yet achieved final height, and we cannot exclude the possibility of a further CG during puberty and adolescence (2).

The observation that CG children were heavier at birth than NCG subjects suggests that prenatal weight gain may have long-term consequences on growth performance or that factors affecting intrauterine growth (i.e. genes) may continue to exert their negative influence during postnatal life as recently proposed (25). Postnatal nutritional status, however, may play a crucial role in allowing $\mathrm{CG}$, as suggested by the finding of a higher body mass index in $\mathrm{CG}$ children.

No significant difference in the IGF system-related variables was found in the two groups. This finding is consistent with previous reports showing that cord blood levels of IGFs and IGFBPs are not predictive of CG in IUGR children $(3,4)$. However, height is the result of the dynamic and continuous process of growth, and we cannot rule out the possibility of a transient imbalance or insufficiency of the IGF system in critical periods of the growth process. GH secretory abnormalities and reduced levels of IGFs have recently been described in IUGR children, and GH therapy has been proposed to improve their growth (26-31). Our observation of no significantly different values of the IGF system-related variables in

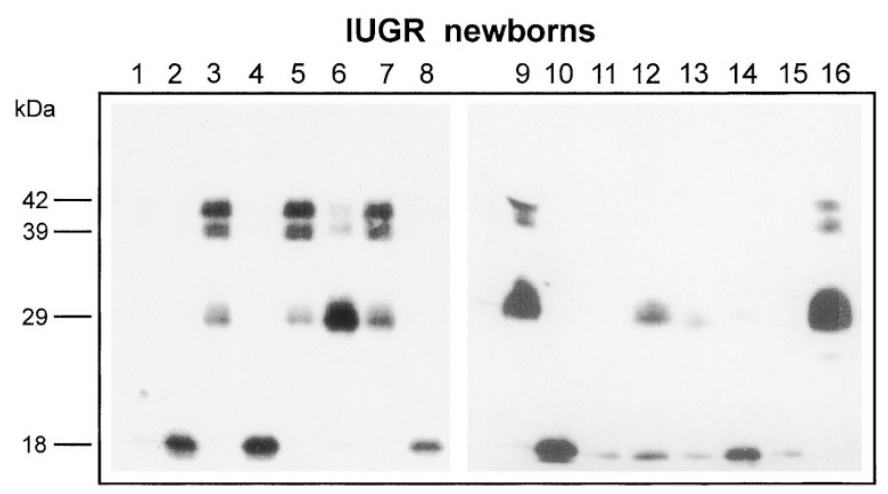

Figure 3. Detection of IGFBP-3 forms by Western immunoblotting in sera from 15 IUGR newborns. Lanes 1-15, IUGR newborn samples. Lane 16, normal adult sample. Molecular mass markers are indicated on the left. 


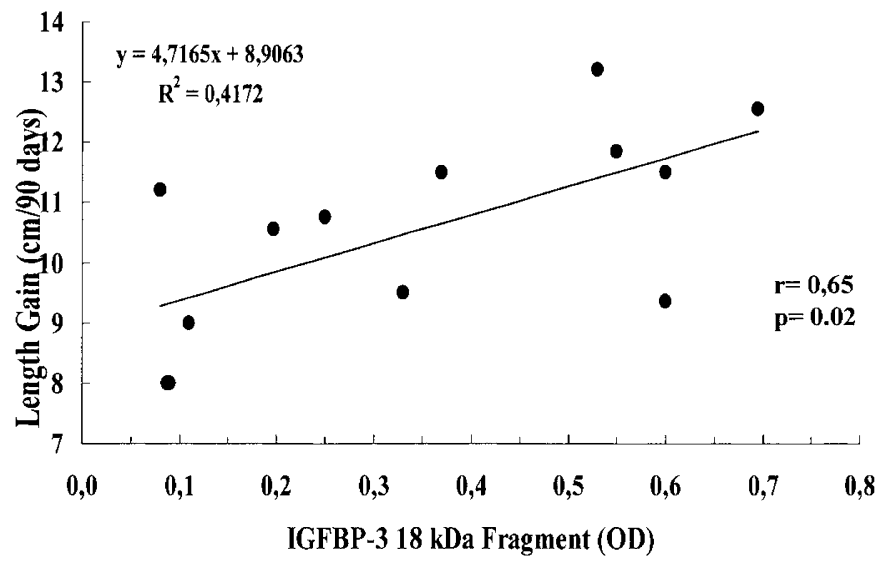

Figure 4. Relationship between the relative intensity of the IGFBP-3 18-kD fragment and length gain $(\mathrm{cm})$ in the first 3 months of postnatal life. The 18-kD band intensity was determined by densitometry and was expressed in OD.

IUGR children who had caught up and those who did not questions the pathophysiologic role of IGFs (and consequently $\mathrm{GH})$ in the growth failure of IUGR subjects.

The CG was inversely related to cortisol levels: the higher the cortisol concentrations the lower the CG. Furthermore, we found an inverse relationship between cortisol and birth weight. This finding is consistent with the report of Phillips et al. (18), showing plasma cortisol concentrations to be inversely related to birth weight and associated with raised blood pressure and insulin resistance in adults. Houang et al. (32) have recently reported that IUGR children may have a higher cortisol to cortisone ratio that was inversely related to height in childhood, and suggested a partial deficiency of $11 \beta$ hydroxysteroid dehydrogenase type 2 . In keeping with this observation, our results suggest that adrenal output of cortisol, although remaining within the normal range, may affect CG in IUGR children. It is tempting to speculate that intrauterine reprogramming of HPAA secondary to malnutrition or chronic stress may permanently influence adrenal function. A number of observations seem to be in accordance with our hypothesis. Exposure to glucocorticoids in utero has repeatedly been reported to result in hyperactivity of the HPAA in postnatal life

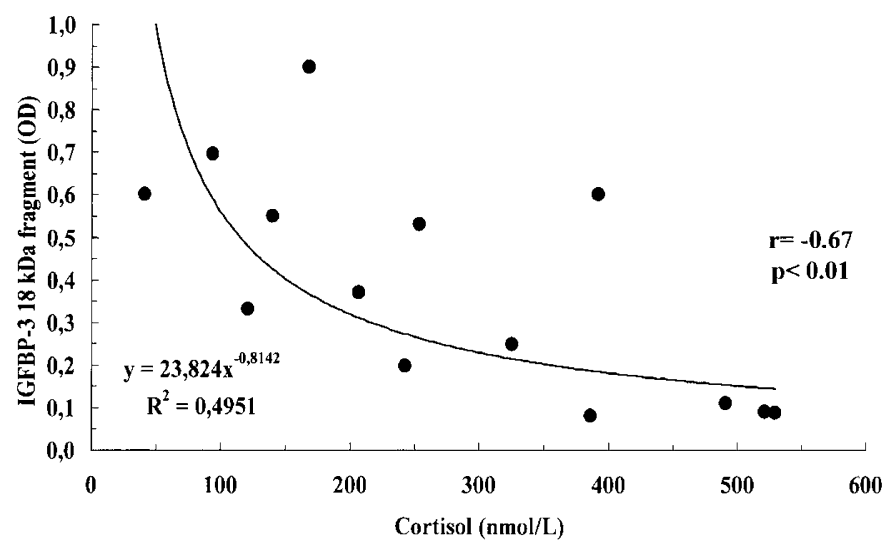

Figure 5. Relationship between cortisol concentrations and the relative intensity of the IGFBP-3 18-kD fragment. Cortisol was determined by RIA. The $18-\mathrm{kD}$ band intensity was determined by densitometry and was expressed in OD.
(33). IUGR children have been shown to present an exaggerated adrenarche, and a reprogramming of adrenal secretion of dehydroepiandrosterone has been proposed (34). In addition, it is interesting to note that two dexamethasone-treated fetuses with congenital adrenal hyperplasia have been reported to have severe postnatal growth failure (35). On the other hand, we have recently reported that children with a congenital form of chronic adrenal insufficiency such as familial glucocorticoid deficiency are tall (36).

Glucocorticoids are potent modulators of the IGF system, being able to reduce the local expression of IGF-I $(37,38)$ and increase that of a potent inhibitor of IGF-I such as IGFBP-1 $(39,40)$, and we first described the close relationship of cortisol with IGF-I (negative) and IGFBP-1 (positive) in human cord blood (19).

Reanalysis of cord blood samples from IUGR newborns in whom we previously reported an inverse correlation between cortisol levels and the length gain in the first trimester of life (19) has enabled us to observe an inverse relationship between cortisol and the smaller IGFBP-3 fragment, which, in turn, directly correlated with the first trimester length gain. This finding suggests a novel mechanism by which cortisol might negatively modulate growth at least during the perinatal period: by influencing IGFBP-3 proteolysis. If, as suggested (4), IGFBP-3 proteolysis increases IGF bioavailability in IUGR infants, thus allowing early CG in most of them, cortisol-induced inhibition of IGFBP proteolysis might affect early length gain and compromise longterm growth. However, IGFBP-3 immunoblot analysis during childhood failed to detect the $18-\mathrm{kD}$ fragment, and no relationship was demonstrated between cortisol and the approximately $29 \mathrm{kD}$ fragment relative amount, indicating that the inverse relationship between cortisol levels and IGFBP-3 proteolysis seems to be limited to perinatal period and, probably, to the protease yielding the $18-\mathrm{kD}$ fragment. The potential mechanisms used by glucocorticoids to reduce IGFBP-3 proteolysis in vivo are unknown at the moment. We previously reported that the addition of cortisol $(50-1000 \mathrm{nM})$ to normal adult serum coincubated with a protease-rich serum from pregnant woman during the third trimester failed to inhibit IGFBP-3 proteolysis (41), whereas 12-h cortisol treatment (100 and $500 \mathrm{nM}$ ) of human neuroblastoma cells (SHSY5Y line) appeared to reduce IGFBP-3 proteolysis in cell medium (41).

A high proportion of our IUGR children (almost 10\%) showed abnormally elevated LDL cholesterol levels, which were significantly increased in NCG subjects. This finding is consistent with a recent report showing increased LDL cholesterol levels in almost 9\% of IUGR children (42). Furthermore, our data indicate that poor CG is associated with higher LDL cholesterol concentrations as recently suggested (43).

The soluble form of IGF2R results from proteolytic cleavage of the transmembrane region of the intact receptor and, by binding IGF-II, induces its degradation and inhibits its mitotic actions (44, 45). Despite their mutual antagonism, or in virtue of this, IGF-II and IGF2R concentrations have been found to be positively related (46) as observed in our IUGR children. Our observation of the relationship of IGF2R levels with total and LDL cholesterol concentrations is challenging. Although association does not prove causality, it is noteworthy that when cholesterol accumu- 
lates in intracellular late-endosomes, the bidirectional traffic of IGF2R between trans-Golgi network and late-endosomes is altered, causing an increase of IGF2R in these organelles $(47,48)$. Therefore, at the intracellular level, altered cholesterol concentrations are able to redistribute IGF2R, and similarly, an effect of increased cholesterol circulating levels on the soluble form of IGF2R might be hypothesized, although the physiologic significance appears, at the moment, unclear.

In conclusion, our results suggest that CG in IUGR children might be affected by intrauterine reprogramming of the HPAA, which may result in a permanent modification of the neuroendocrine response to stress. Children with increased cortisol secretion may be at higher risk of growth failure. In the neonatal period, cortisol might act by limiting IGFBP-3 proteolysis and, therefore, reducing IGF bioavailability.

\section{REFERENCES}

1. Fitzhardinge PM, Stevan EM 1972 The small for date infant. I. Later growth patterns. Pediatrics 49:671-681

2. Karlberg J, Albertsson-Wikland K 1995 Growth in full-term small-for-gestational-age infants: from birth to final height. Pediatr Res 38:733-739

3. Leger J, Noel M, Limal KM, Czernichow P 1996 Growth factors and intrauterine growth retardation. II. Serum growth hormone, insulin-like growth factor-I, and IGF-binding protein-3 levels in children with intrauterine growth retardation compared with normal control subjects: prospective study from birth to two years of age. Pediatr Res 40:101-107

4. Cianfarani S, Germani D, Rossi P, Rossi L, Germani A, Ossicini C, Zuppa A, Argirò G, Holly JMP, Branca F 1998 Intrauterine growth retardation: evidence for the activation of the insulin-like growth factor (IGF)-related growth-promoting machinery and the presence of a cation-independent IGF binding protein-3 proteolytic activity by two months of life. Pediatr Res $44: 374-380$

5. Jones JL, Clemmons DR 1995 Insulin-like growth factors and their binding proteins. Endocr Rev 16:3-34

6. Baxter RC, Martin JL, Beniac VA 1989 High molecular weight insulin-like growth factor complex; purification and properties of the acid-labile subunit from human serum. J Biol Chem 264:11843-11848

7. Giudice LC, Farrell EM, Pham H, Lamson G, Rosenfeld RG 1990 Insulin-like growth factor binding proteins in maternal serum throughout gestation and in the puerperium: effects of a pregnancy-associated serum protease activity. J Clin Endocrinol Metab 71:806-816

8. Hossenlopp P, Sergovia B, Lassarre C, Roghani M, Bredon M, Binoux M 1990 Evidence of enzymatic degradation of insulin-like growth factor-binding proteins in the $150 \mathrm{~K}$ complex during pregnancy. J Clin Endocrinol Metab 71:797-805

9. Blat C Villaudy J, Binoux M 1994 In vivo proteolysis of serum insulin-like growth factor (IGF) binding protein-3 results in increased availability of IGF to target cells. J Clin Invest 93:2226-2229

10. Barker DJP, Winter PD, Osmond C, Margetts B 1989 Weight in infancy and death from ischemic heart disease. Lancet 2271:577-580

11. Barker DJP, Hales CN, Fall CHD, Osmond C, Phipps K, Clark PMS 1993 Type 2 (non-insulin dependent) diabetes mellitus, hypertension and hyperlipidemia (syndrome X): relation to reduced fetal growth. Diabetologia 36:62-67

12. Barker DJP 1997 Intrauterine programming of coronary heart disease and stroke. Acta Paediatr Suppl 423:178-182

13. Levine $\mathrm{S} 1957$ Maternal and environmental influences on the adrenocortical response to stress in weanling rats. Science 156:258-260

14. Meaney MJ, Aitken DH, Sharma S, Viau V 1992 Basal ACTH, corticosterone and corticosterone binding globulin levels over the diurnal cycle, and age-related changes in hippocampal type I and type II corticosteroid receptor binding capacity in young and aged, handled and non handled rats. Neuroendocrinology 55:204-213

15. Barbazanges A, Piazza PV, Le Moal M, Maccari S 1996 Maternal glucocorticoid secretion mediates long-term effects of prenatal stress. J Neurosci 16:3943-3949

16. Dodic M, Peers A, Coghlan JP, Wintour M 1999 Can excess glucocorticoid, in utero, predispose to cardiovascular and metabolic disease in middle age? Trends Endocrinol Metab 10:86-91

17. Lesage J, Blondeau B, Grino M, Breant B, Dupouy JP 2001 Maternal undernutrition during late gestation induces fetal overexposure to glucocorticoids and intrauterine growth retardation, and disturbs the hypothalamo-pituitary adrenal axis in the newborn rat. Endocrinology 142:1692-1702

18. Phillips DIW, Barker DJP, Fall CHD, Seckl JR, Whorwood CB, Wood PJ, Walker BR 1998 Elevated plasma cortisol concentrations: a link between low birth weight and the insulin resistance syndrome? J Clin Endocrinol Metab 83:757-760

19. Cianfarani S, Germani D, Rossi L, Argirò G, Boemi S, Lemon M, Holly JMP, Branca F 1998 IGF-I and IGF-binding protein-1 are related to cortisol in human cord blood. Eur J Endocrinol 138:524-529
20. Lubchenco LO, Hansman C, Dressler M, Boyd R 1963 Intrauterine growth as estimated from liveborn birth weight data at 24 to $42 \mathrm{wk}$ of gestation. Pediatrics 32:793-800

21. Tanner JM, Whitehouse RH 1976 Clinical longitudinal standards for height, weight, height velocity, weight velocity and stages of puberty. Arch Dis Child 51:170-179

22. Lubchenco LO, Hansman C, Boyd R 1966 Intrauterine growth in length and head circumference as estimated from live births at gestational ages from 26 to $42 \mathrm{wk}$. Pediatrics 37:403-408

23. Costello M, Baxter RC, Scottt RC 1999 Regulation of soluble insulin-like growth factor II/mannose 6-phsphate receptor in human serum: measurement by enzymelinked immunosorbent assay. J Clin Endocrinol Metab 84:611-617

24. Friedewald WT, Levy RJ, Fredrickson DS 1972 Estimation of the concentration of low-density-lipoprotein cholesterol in plasma without use of the preparative ultracentrifuge. Clin Chem 18:499-502

25. Hatterssley AT, Tooke JE 1999 The fetal insulin hypothesis: an alternative explanation of the association of low birth weight with diabetes and vascular disease. Lancet 353:1789-1792

26. Albertsson-Wikland K 1989 Growth hormone secretion and growth hormone treatment in children with intrauterine growth retardation. Swedish Paediatric Study Group for Growth Hormone Treatment. Acta Paediatr Scand Suppl 349:35-41

27. Stanhope R, Preece MA, Hamill G 1991 Does growth hormone treatment improve final height attainment of children with intrauterine growth retardation? Arch Dis Child 66:1180-1183

28. de Waal WJ, Hokken-Koelega ACA, Stijnen T, de Muinck Keizer-Schrama SMPF, Drop SLS 1994 Endogenous and stimulated GH secretion, urinary GH excretion, and plasma IGF-I and IGF-II levels in prepubertal children with short stature after intrauterine growth retardation. Clin Endocrinol 41:621-630

29. Boguszewski M, Rosberg S, Albertsson-Wikland K 1995 Spontaneous 24-hour growth hormone profiles in prepubertal small for gestational children. J Clin Endocrinol Metab 80:2599-2606

30. de Zegher F, Maes M, Gargosky SE, Heinrichs C, Du Caju MV, Thiry G, De Schepper J, Craen M, Breysem L, Lofstrom A, Jonsson P, Bourguignon JP, Malvaux P, Rosenfeld RG 1996 High-dose growth hormone treatment of short children born small for gestational age. J Clin Endocrinol Metab 81:1887-1892

31. Boguszewski M, Albertsson-Wikland K, Aronsson S 1998 Growth hormone treatment of short children born small-for-gestational-age: the Nordic Multicentre Trial. Acta Paediatr 87:257-263

32. Houang M, Morineau G, Le Bouc Y, Fiet J, Gourmelen M 1999 The cortisolcortisone shuttle in children born with intrauterine growth retardation. Pediatr Res 46:189-193

33. Matthews SG 2000 Antenatal glucocorticoids and programming of the developing CNS. Pediatr Res 47:291-300

34. Francois I, de Zegher F 1997 Adrenarche and fetal growth. Pediatr Res 41:440-442

35. Lajic S, Wedell A, Bui TH, Ritzen EM, Holst M 1998 Long-term somatic follow-up of prenatally treated children with congenital adrenal hyperplasia. J Clin Endocrinol Metab 83:3872-3880

36. Elias LL, Huebner A, Metherell LA, Canas A, Warne GL, Manca Bitti ML, Cianfarani S, Clayton PE, Savage MO, Clark AJ 2000 Tall stature in familial glucocorticoid deficiency. Clin Endocrinol 53:423-430

37. Delany AM, Canalis E 1995 Transcriptional repression of insulin-like growth factor-I by glucocorticoids in rat bone cells. Endocrinology 136:4776-4781

38. Swolin D, Brantsing C, Matejka G, Ohlsson C 1996 Cortisol decreases IGF-I messenger-RNA levels in human osteoblast-like cells. J Endocrinol 149:397-403

39. Conover CA, Divertie GD, Lee PDK 1993 Cortisol increases plasma insulin-like growth factor binding protein-1 in humans. Acta Endocrinol 128:140-143

40. Conover CA, Lee PDK, Riggs BL, Powell DR 1996 Insulin-like growth factor binding protein-1 expression in cultured human bone-cells: regulation by insulin and glucocorticoids. Endocrinology 137:3295-3301

41. Cianfarani S, Germani D, Geremia C 1999 Cortisol levels are inversely related to the major fragment of IGFBP-3 $(\sim 29 \mathrm{kDa})$ in IUGR children. A novel regulatory mechanism for perinatal growth? J Pediatr Endocrinol Metab 12 (suppl 2):705 (abstr 3)

42. Sas T, Mulder P, Hokken-Koelega A 2000 Body composition, blood pressure, and lipid metabolism before and during long-term growth hormone $(\mathrm{GH})$ treatment in children with short stature born small for gestational age either with or without GH deficiency. J Clin Endocrinol Metab 85:3786-3792

43. Tenhola S, Martikainen A, Rahiala E, Herrgard E, Halonen P, Voutilainen R 2000 Serum lipid concentrations and growth characteristics in 12-year-old children born small for gestational age. Pediatr Res 48:623-628

44. Scott CD, Ballesteros M, Madrid J, Baxter RC 1996 Soluble insulin-like growth factor-II/mannose 6-phosphate receptor inhibits deoxyribonucleic acid synthesis in cultured rat hepatocytes. Endocrinology 137:873-878

45. Scott CD, Weiss J 2000 Soluble insulin-like growth factor-II/mannose 6-phosphate receptor inhibits DNA synthesis in insulin-like growth factor II sensitive cells. J Cell Physiol 182:62-68

46. Ong K, Kratzsch J, Kiess W, Costello M, Scott C, Dunger D 2000 Size at birth and cord blood levels of insulin, insulin-like growth factor-I (IGF-I), IGF-II, IGF-binding protein-1 (IGFBP-1), IGFBP-3, and the soluble insulin-like growth factor-II/mannose 6-phosphate receptor in term human infants. J Clin Endocrinol Metab 85:4266-4269

47. Kobayashi T, Beuchat MH, Lindsay M, Frias S, Palmiter RD, Sakuraba H, Parton RG, Gruenberg J 1999 Late endosomal membranes rich in lysobisphosphatidic acid regulate cholesterol transport. Nat Cell Biol 1:113-118

48. Mukherjee S, Maxfield FR 1999 Cholesterol: stuck in traffic. Nat Cell Biol 1:E37-E38 